\title{
Seeking key meteorological parameters to better understand Hector
}

\author{
S. Gentile ${ }^{1}$ and R. Ferretti ${ }^{1,2}$ \\ ${ }^{1}$ Department of Physical and Chemical Sciences/CETEMPS, University of L'Aquila, Via Vetoio, \\ 67010 Coppito, L’Aquila, Italy \\ ${ }^{2}$ Danish Meteorological Institute, Lyngbyvej 100, 2100 Copenhagen, Denmark
}

Correspondence to: S. Gentile (sabrina.gentile@aquila.infn.it)

Received: 30 April 2015 - Published in Nat. Hazards Earth Syst. Sci. Discuss.: 4 June 2015

Accepted: 23 December 2015 - Published: 11 February 2016

\begin{abstract}
Twelve Hector events, a storm which develops in northern Australia, are analyzed with the aim of identifying the main meteorological parameters involved in the storm's convective development. Based on Crook's ideal study (Crook, 2001), wind speed and direction, wind shear, water vapor, convective available potential energy and type of convection are the parameters used for this analysis. Both the European Centre for Medium-Range Weather Forecasts (ECMWF) analysis and high-resolution simulations from the Fifth-Generation Mesoscale Model (MM5) are used. The MM5 simulations are used to connect the mean vertical velocity to the total condensate at the maximum stage and to study the dynamics of the storms. The ECMWF analyses are used to evaluate the initial conditions and the environmental fields contributing to Hector's development. The analysis suggests that the strength of convection, defined in terms of vertical velocity, largely contributes to the vertical distribution of hydrometeors. The role of total condensate and mean lifting versus low-level moisture, convective available potential energy, surface wind and direction is analyzed for shear and no-shear conditions to evaluate the differences between type A and B for real events. Results confirm the tendency suggested by Crook's analysis. However, Crook's hypothesis of low-level moisture as the only parameter that differentiates between type A and B can only be applied if the events develop in the same meteorological conditions. Crook's tests also helped to assess how the meteorological parameters contribute to Hector's development in terms of percentage.
\end{abstract}

\section{Introduction}

Hector is a vigorous convective system that develops on the Tiwi Islands, two islands included in the "Maritime Continent" (Ramage, 1968), an area extending across the Indonesian archipelago, north Australia and New Guinea. This is one of the primary regions of global latent heat release contributing to the forcing of planetary-scale circulations (e.g., Hadley and Walker cells). The Tiwi Islands, located in the northern tropical part of Australia, produce regular tropical convection during the pre-monsoon and monsoon "break" seasons (from November to March) in response to the latent heat released during the diurnal cycle (Keenan and Carbone, 1992).

This storm has been analyzed during observing campaigns like ITEX (Island Thunderstorm Experiment, 1988), MCTEX (Maritime Continent Thunderstorm Experiment, 1995), SCOUT-O3 (Stratospheric-Climate links with emphasis On the Upper Troposphere and lower stratosphere, 2005) and TWP-ICE (Tropical Warm Pool - International Cloud Experiment, 2006) whose aims were to better understand the triggering mechanisms and the meteorological parameters favorable to the convective development. Particularly the MCTEX campaign collected many environmental factors that are known or believed to influence the initiation, organization, propagation and intensity of deep convection. In addition this data set allowed two distinct forcing regimes leading to Hector to be defined (Carbone et al., 2000):

1. type A: resulting from the confluence and convergence of the sea breeze fronts;

2. type B: rising from the interaction between sea breeze and gust front, convectively generated by cold pools. 
Type A forcing may be viewed as nature's backup mechanism when the meteorological conditions do not allow type B development.

Following these campaigns, some ideal and real numerical studies have been performed to understand the forcing and the triggering mechanisms of the Hector storm (e.g., Golding, 1993; Crook, 2001; Saito et al., 2001; Ferretti and Gentile, 2009; Gentile et al., 2014).

Golding (1993) used the UK Met Office's mesoscale model at $3 \mathrm{~km}$ resolution initialized by a sounding to examine two cases from ITEX. The results suggest that the model qualitatively reproduces the diurnal evolution of Hector, showing a clear relationship between the storm development and the island topography. Saito et al. (2001) used the Japanese Meteorological Institute's mesoscale model at $1 \mathrm{~km}$ resolution to simulate a case from MCTEX. The study highlights a good agreement between the simulations and observations and focuses on the five stages of the convective life cycle.

Chemel et al. (2009) simulated the 30 November 2005 Hector event using two models, the Advanced Research Weather Research and Forecasting (ARW) model, and the Met Office Unified Model, with a resolution of $1 \mathrm{~km}$. Both models reproduce the development of Hector fairly well, even though the two simulated surface heat fluxes are very different. This would mean that the intensity of the storm is not only controlled by this factor. The aim of the paper is to investigate the role of deep convection in the vertical transport of tropospheric air into the lower stratosphere. Chemel et al. (2009) conducted a further simulation with ARW in large eddy simulation (LES) mode, refining the grid spacing to $250 \mathrm{~m}$, and concluded that the characteristics of the Hector storm are basically similar in time and space to those obtained in the $1 \mathrm{~km}$ resolution. Therefore a $1 \mathrm{~km}$ resolution is fine enough to simulate the timing, the structure and strength of deep convection when compared with the field campaign observations (Chemel et al., 2009).

In the study by Ferretti and Gentile (2009) two Hector events (one observed during SCOUT-O3 and one during TWP-ICE) have been investigated, analyzing the dynamics and thermodynamics. Using the Fifth-Generation Mesoscale Model (MM5) at $1 \mathrm{~km}$ resolution over the Tiwi Islands, several numerical experiments have been performed with the aim of understanding the forcing and triggering conditions for the development of Hector. The study demonstrates the key role of the sea breeze, water vapor content and soil moisture content in the growth of Hector. Moreover, Gentile et al. (2014) carried out a study for highlighting both the triggering factors and microphysical structure of a Hector event. The event was analyzed using MM5 model simulations, groundbased radar and TRMM (Tropical Rainfall Measuring Mission ) satellite data, with the aim of understanding the mechanisms leading to the convective development. The analysis of the horizontal and vertical structure at high temporal and spatial resolution produced by MM5 allows the mech- anisms for triggering Hector to be established: sea breeze, a gust front from previous convection and the channeling effect by topography.

Zhu et al. (2013) simulated four cases of the Hector storm by running the ARW model with a maximum horizontal resolution of $1 \mathrm{~km}$, incorporating and not incorporating the observations collected during the ACTIVE campaign. Only one (30 November 2005) of the four cases was well simulated by the run without the inclusion of observations. Three events (16 November, 6 and 10 February 2006) can be simulated only if the model was run incorporating observations. The major deficiency deduced by Zhu et al. (2013) in the simulations of Hector is the smaller size and the weaker intensity in comparison with the observations.

Simulations were performed for a Hector event observed on 30 November 2005 by Dauhut et al. (2014) using the Meso-NH (mesoscale non-hydrostatic) model, performed with a grid spacing of $1600,800,400,200$ and $100 \mathrm{~m}$. The updraft generally decreases with reduced resolution due to the reduced entrainment into the base of the updrafts. Indeed, the strong updrafts in the boundary layer obtained by the three finest simulations reinforce the updrafts in the upper troposphere.

Crook (2001) performed an ideal study using both a linear and nonlinear flow model for assessing the most important parameters of the Hector convective system. The lowlevel moisture is found to be an important parameter for differentiating between type A and B. High values of lowlevel moisture correspond to earlier convection, then the associated evaporational cooling produces cold pools that retard the further inland progress of the sea breezes. Hence, Hector type B develops because of the convergence of the sea breeze and the gust front related to previous convection. Hector type A, which is associated with low values of lowlevel moisture, develops when the generation of precipitating cold pools is delayed so that the sea breeze fronts have time to converge. Moreover, Crook (2001) performed sensitivity tests to surface heating, wind speed and direction. The results show a strong link between convective available potential energy (CAPE), wind speed and direction and total condensate (sum of all hydrometeors) of Hector cells. The relationship between couples of meteorological parameters was investigated using diagrams that allowed it to be assessed that the convective strength, in terms of vertical velocity, increases as the wind speed decreases and as the wind direction turns toward the major axis of the Tiwi Islands (Crook, 2001).

In this study, 12 Hector events (from November 1995 to November 2008) are used to investigate the transferability of the conclusions of Crook's study to real events. With this aim, the relationship with the same meteorological parameters used by Crook is investigated for each real Hector event, each one characterized by its own boundary and initial conditions. The case studies are simulated using the MM5 as described in Ferretti and Gentile (2009) and Gentile et al. (2014), and the results are investigated to establish the contri- 
bution of water vapor, surface wind speed and direction to the convective strength. These previous works (Ferretti and Gentile, 2009; Gentile et al., 2014) allow the model's ability to reproduce the dynamics and correctly detect the triggering factors leading to the development of Hector to be assessed, by performing a detailed comparison with observations. However, a temporal and spatial shift is found for MM5. This is also a common issue found for the WRF (Weather Research and Forecasting) model by Chemel et al. (2009) and Zhu et al. (2013). The main focus of this study, as already pointed out, is to investigate the role of a few key meteorological parameters for Hector's development by using Crook's diagrams, which are independent of time. Therefore, a possible temporal or spatial shift in the MM5 simulations of Hector does not affect the results.

The study is organized as follows. A meteorological analysis of the events is presented in Sect. 2 as a function of wind speed, wind direction and shear, CAPE and water vapor and convection modes $\mathrm{A}$ or $\mathrm{B}$, with a brief description of the model configuration. The comparison, in terms of cloud total condensate and vertical velocity profiles among the 12 events, is shown in Sect. 3. The fourth paragraph describes Crook's test and outlines the main features in terms of percentage involved in Hector's development. Conclusions are drawn in Sect. 5.

\section{Meteorological characteristics of the Hector events}

The convective strength of the tropical storm Hector is evaluated using the meteorological variables suggested by Crook (2001). In this study, 12 real events (eight single-cell and two double-cell) are selected. Some of them (20 November 1995; 23 November 1995; double-cell 27 November 1995; 1 and 4 December 1995) were observed during MCTEX, a campaign held in late 1995 on the Tiwi Islands with the goal of monitoring the convective life cycle of the mesoscale convective system (Keenan and Carbone, 1992; Carbone et al., 2000). Four of the remaining events (the double-cell 30 November 2005, 6 February 2006 and 29 November 2007) have already been analyzed by Ferretti and Gentile (2009) and Gentile et al. (2014). The events are named with the acronyms as follows:

\section{20 November 1995: N20;}

2. 23 November 1995: N23;

3. 27 November 1995: N27 (double-cell);

4. 1 December 1995: D1;

5. 4 December 1995: D4;

6. 30 November 2005: N30 (double-cell);

7. 6 February 2006: F6;

\section{29 November 2007: N29;}

9. 11 November 2007: N11;

\section{17 November 2008: N17.}

To simulate the events, the same configuration is used as in Ferretti and Gentile (2009) and Gentile et al. (2014). The previous works (Ferretti and Gentile, 2009; Gentile et al., 2014) allow the model's ability to reproduce the dynamics and correctly detect the triggering factors leading to the development of Hector to be assessed, by performing a detailed comparison with radar and satellite observations. The mesoscale model, MM5V3, is a non-hydrostatic, fully compressible, primitive equation model with a terrain following vertical coordinates (Dudhia et al., 2004). Four nested domains and 58 vertical levels are used. The mother domain has a $27 \mathrm{~km}$ grid, covering the tropical part of Australia. The finest domain has a horizontal grid of $1 \mathrm{~km}$ and it is centered over the Tiwi Islands. The following parametrizations are used: the Gayno-Seaman scheme for the planetary boundary layer; the MM5 cloud radiation scheme for radiative transfer processes; the Kain-Fritsch cumulus convection parametrization for domains 1,2 and 3 (though there is no cumulus convective parametrization for the finest domain); the Reisner 2 parametrization as a microphysical scheme. To improve the meteorological analysis on the mesoscale grid, direct surface and radiosonde observations have been incorporated using the objective analysis based on the Cressman scheme (Faccani et al., 2003). The simulations are initialized using ECMWF (European Centre for Medium-Range Weather Forecasts) analysis at $0.25^{\circ}$ and they last $24 \mathrm{~h}$ for all the events. The boundary conditions are upgraded every $6 \mathrm{~h}$.

In the following subsections, the ECMWF analysis is used to analyze the main dynamical aspects of the Hector events. The analysis is performed, evaluating the role of the following parameters in the development of the Hector storm: the wind speed and direction at three different levels (lower (LL, $950 \mathrm{hPa}$ ), medium (ML, $700 \mathrm{hPa}$ ) and upper levels (UL, $300 \mathrm{hPa})$ ), the CAPE and the water vapor content extracted at $950 \mathrm{hPa}$ (mixing ratio). The values of these parameters for the Hector events are summarized in Table 1. To better understand the dynamical conditions for the storm development, two parameters are added: the shear occurrence and the typology of the events (definition based on Carbone et al., 2000). All these quantities are derived from the ECMWF analysis at 00:00 UTC (09:30 LST). For the second cells (marked in the table as 2), the meteorological parameters are extracted $6 \mathrm{~h}$ later, that is, at 06:00 UTC (15:30 LST). Indeed, the ECMWF analysis is only provided for base times of 00:00, 06:00, 12:00 or 18:00, so it is not possible to obtain meteorological information for a time interval of less than $6 \mathrm{~h}$ (the first cell of $\mathrm{N} 27$ reaches maximum development at 13:10 LST and the second one, $3 \mathrm{~h}$ later, at 16:10 LST; for 
$\mathrm{N} 30$, the maximum of the first cell is reached at 14:30 LST and the second one at 15:50 LST).

\subsection{Wind speed}

The wind speed at the surface controls the magnitude of convective instability over the Tiwi Islands; indeed, as the wind speed decreases, the low-level air mass spends more time over the heated and moistened island, increasing its instability (Crook, 2001).

Hector D1 and N29 present weak wind at the surface with a maximum of $2.5 \mathrm{~m} \mathrm{~s}^{-1}$ (Table 1) from south for D1 and from east for N29 (Fig. 1a, e). N17 and N20 are also characterized by very weak wind at the lower level with a maximum speed of $2 \mathrm{~m} \mathrm{~s}^{-1}$, from the southeast and the north, respectively, but in addition, weak wind is also found at $700 \mathrm{hPa}$ (Fig. 2c, d, e, f). These conditions are favorable for increasing the instability which allows for the vertical growth of the tropical thunderstorm. On the contrary, N11 and F6 show a very strong southeasterly wind up to $16-18 \mathrm{~m} \mathrm{~s}^{-1}$ and a moderate easterly wind of $8 \mathrm{~m} \mathrm{~s}^{-1}$, respectively, at the middle level (Figs. 2b, 3b), allowing more stable conditions and an unfavorable environment to be supposed for the vertical growth. D4 and N23 have very similar wind structure; both events have a weak westerly flow (less than $3 \mathrm{~m} \mathrm{~s}^{-1}$ ) at the lower levels (Figs. 1c, 3c) and a sharp change of wind direction at the middle level, with a speed of approximately $5 \mathrm{~m} \mathrm{~s}^{-1}$ (Figs. 1d, 3d). Finally, the initial conditions of N27 (double-cell event) show a very weak surface wind, characterized by a speed of $1.5-2.5 \mathrm{~m} \mathrm{~s}^{-1}$ (Fig. 4e, Table 1), produced by an area of high pressure centered on the Tiwi Islands (Fig. 4f). In contrast, the double-cell event (N30) shows a moderate wind speed (approximately $5 \mathrm{~m} \mathrm{~s}^{-1}$ ) at the three levels, changing direction at higher altitudes (Table 1, Fig. $4 a, b)$. For these two events, the environmental conditions prior to the organization and the development of the second convective cell are more unstable and disorganized than the single-cell events, as suggested by the fast low-level wind (Table 1, Fig. 4c, g, d, h) produced by the gust front of the previous cell.

\subsection{Wind direction and shear}

The wind direction is another meteorological parameter affecting the development of Hector. Assuming that the Tiwi Islands have an ellipse shape, if the air mass blows along the major axis (east-west), the low-level convergence, produced by the sea breeze and the surface wind, is maximized because of the longer time spent by the air mass over the heated and moistened surface of Tiwi Islands. In contrast, if the air mass blows along the minor axis (north-south), the low-level convergence is reduced, both by the shorter time spent by the air mass over the heated surface, and by the overlapping of the surface wind in the same direction of the sea breeze, producing a much weaker convection (Crook, 2001). In addition, the vertical wind shear (change of direction) enhances the instability, allowing for the vertical growth of the cell (Crook, 2001).

The D4, F6 and N23 events show a similar flow structure characterized by a strong and sharp vertical wind shear (Table 1); the westerly surface wind (Figs. 1c, 3a, c) turns $180^{\circ}$, becoming easterly at middle level (Fig. 1d, 3b, d). Hectors $\mathrm{N} 11$ and N20 show shears from a different direction: a surface flow from the southwest and from the north (Fig. 2a, e for N11 and N20) and a strong southeasterly (N11, Fig. 2b) and moderate south wind (N20, Fig. 2f) at the middle level, respectively. Figures 1a, e and 2c show the lack of a change in the wind direction between the low and the middle level, which confirms the absence of the shear (Fig. 1b, f and 2d) for D1, N29 and N17. Finally, for the two double-cell events, no wind shear is detected for N27 (Fig. 4e, f): the easterly wind is constant up to middle level. A strong vertical wind shear is found for N30 (Fig. 4a, b): the lower level wind turns from a northwesterly to an easterly direction at $700 \mathrm{hPa}$. This structure lasted until the onset of the second cell (Fig. 4c, d). For what concerns the environment in which the second convective cell develops, it is more heterogeneous: the onset of a weak wind shear helps to develop the N27 second cell (Table 1 , Fig. $4 \mathrm{~g}, \mathrm{~h}$ ) and the stable presence of a strong vertical wind shear contributes to the growth of the N30 second cell (Table 1, Fig. 4c, d).

\subsection{CAPE and water vapor}

The CAPE is the vertical integral of positive buoyancy of an air parcel and it is an indicator of atmospheric instability. Results from the MCTEX campaign showed that the variability of CAPE is mainly due to the variability of the low-level moisture. Therefore, the two parameters are directly proportional (Crook, 2001).

Four single-cell cases are characterized by high values of CAPE (greater than $1200 \mathrm{~J} \mathrm{~kg}^{-1}$ and lower than $2500 \mathrm{~J} \mathrm{~kg}^{-1}$ ): D1, D4, N23 and N29 (Table 1). All these events show a remarkable convective activity, with several cells developing before and/or after the main Hector cell. The doublecell events present wet conditions with a high value of CAPE $\left(2000 \mathrm{~J} \mathrm{~kg}^{-1}\right)$ and mixing ratio of water vapor $\left(18-19 \mathrm{~g} \mathrm{~kg}^{-1}\right.$, Table 1) for N30, and a dry environment with low CAPE $\left(450 \mathrm{~J} \mathrm{~kg}^{-1}\right)$ and water vapor mixing ratio $\left(16-18 \mathrm{~g} \mathrm{~kg}^{-1}\right.$, Table 1) for N27. However, the second convective cell develops in a more unstable environment for both events; CAPE remains close to $2000 \mathrm{~J} \mathrm{~kg}^{-1}$ for $\mathrm{N} 30$ and increased up to $1650 \mathrm{~J} \mathrm{~kg}^{-1}$ for N27 (Table 1).

The following events were characterized by low values (between 150 and $650 \mathrm{~J} \mathrm{~kg}^{-1}$ ) of CAPE (Table 1): N11, N17, N20 and F6, inferring a weak convective activity. 
Table 1. Meteorological characteristics of the Hector events extracted from ECMWF analysis at 00:00 UTC (09:30 LST) for all the single and first cells of the double-structure events (marked in the table as 1) and at 06:00 UTC (15:30 LST) for the second cells (marked in the table as 2). In the heading LL stands for low level $(950 \mathrm{hPa})$, ML for medium level $(700 \mathrm{hPa})$ and UL for upper level (300 hPa). Wind shear is denoted by "yes" if there is a change of wind direction between LL and ML.

\begin{tabular}{|c|c|c|c|c|c|c|c|}
\hline \multirow[t]{2}{*}{ Events } & \multicolumn{3}{|c|}{$\begin{array}{l}\text { Wind speed/direction } \\
\qquad\left(\mathrm{m} \mathrm{s}^{-1}-\mathrm{deg}\right)\end{array}$} & \multirow[t]{2}{*}{ Shear } & \multirow[t]{2}{*}{$\begin{array}{c}\mathrm{CAPE} \\
\left(\mathrm{J} \mathrm{kg}^{-1}\right)\end{array}$} & \multirow[t]{2}{*}{$\begin{array}{c}q \\
\left(\mathrm{~g} \mathrm{~kg}^{-1}\right)\end{array}$} & \multirow[t]{2}{*}{ Type } \\
\hline & LL & ML & UL & & & & \\
\hline D1 & $1.5-2.5-\mathrm{S}$ & $8-7-\mathrm{SE}$ & $0.5-1.5-\mathrm{E}$ & yes & 1350 & $17-20$ & B \\
\hline D4 & $2-2.5-W$ & $5.5-6-E$ & $6.5-7.5-W$ & yes & 1170 & $18-19.5$ & B \\
\hline F6 & $2.5-3.5-\mathrm{SW}$ & $7-8-E$ & $5-5.5-E$ & yes & 175 & $16.5-17.5$ & B \\
\hline N11 & 3-4-SSW & 16-18-SE & $7-9-\mathrm{NW}$ & yes & 650 & $17.5-21$ & B \\
\hline N17 & $1-2-\mathrm{SE}$ & $1.5-2-E$ & $8-9-W$ & no & 450 & $16-18$ & B \\
\hline $\mathrm{N} 20$ & $<1-\mathrm{N}$ & $3-4.5-S$ & $12-16-W S W$ & yes & 650 & $16.5-17.5$ & B \\
\hline $\mathrm{N} 23$ & $2.5-3.5-W$ & 4-5 - ESE & $10-12-\mathrm{NW}$ & yes & 2500 & $18.5-19.5$ & A \\
\hline $\mathrm{N} 27-1$ & 1.5-2.5 - ENE & $6-7-E$ & $2.5-4-W$ & no & 450 & $16-18$ & A \\
\hline $\mathrm{N} 27-2$ & $2.5-3.5-\mathrm{NNE}$ & 4.5-5.5 - ENE & $3-5-W$ & yes & 1650 & $18-20$ & B \\
\hline $\mathrm{N} 29$ & $1-2.5-E$ & 15-16 - ESE & $7-8.5 \mathrm{NE}$ & no & 2000 & $18-19.5$ & A \\
\hline N30-1 & $3.5-4-\mathrm{NW}$ & 4-5 - ESE & $3-5-S W$ & yes & 2000 & $18-19$ & A \\
\hline N30-2 & $3-5-W$ & 3-4 - ENE & $2-5-S W$ & yes & 1800 & $16-18.5$ & B \\
\hline
\end{tabular}

\subsection{Convection type A or B}

Convection of type A or B is a simple way to differentiate the dynamical development of the storm. Type A convection is generated by the convergence of two sea breeze fronts (Carbone et al., 2000), whereas type B is generated by the convergence of a single sea breeze front and a cold pool produced by previous convection (Crook, 2001; Gentile et al., 2014).

For both double-cell events (N27, N30), the first convective cell develops from the convergence of the two sea breeze fronts (type A) and the second one from the interaction of the gust front of the first decaying cell (type B) with the north and the south sea breeze front, for N27 and N30, respectively (an exhaustive description of the meteorological characteristics of N30 is given by Ferretti and Gentile, 2009). The dynamics of the storm is very similar for both of the events. The first precipitating cells develop in the northeastern part of Melville Island at approximately 12:00 LST. In the following hours, the convective system reaches a first maximum of reflectivity of 55-60 dBz, associated with a strong convective cell (Figs. 5b, 14b of Ferretti and Gentile, 2009) that reaches a height of $16 \mathrm{~km}$ at 13:10 LST for N27 (Fig. 5a) and $14 \mathrm{~km}$ at 14:30 LST for N30 (Fig. 14b of Ferretti and Gentile, 2009). The maximum development of the second cells is reached at 16:10 LST with a height of $16-17 \mathrm{~km}$ for N27 (Fig. 5c, d) and at 15:50 LST with a height of $16 \mathrm{~km}$ for N30 (Fig. 14c, d of Ferretti and Gentile, 2009).

For D1, the maximum development of the storm is reached at 15:10 LST with a height of $16 \mathrm{~km}$ (Fig. 5e, f) after the organization and aggregation of several convective cells. The precipitation starts at 13:00 LST in the northern part of the islands, and a first deep cell develops at 13:50 LST; this last one contributes to the growth of Hector (type B).
Two different Hector developments are found for D4 and $\mathrm{N} 23$, although the rain starts with the front of the south sea breeze for both events (at 13:00 LST for the first and 10:30 LST for the second event). This leads to a first convective tower reaching $10-11 \mathrm{~km}$ at $13: 10$ LST that finally reaches maximum development (type B) at 16:50 LST with a height of $17 \mathrm{~km}$ for D4 (Fig. 5g, h); whereas for N23, the convective line moves quickly to the north west of the Tiwi Islands and interacts with the north breeze front, triggering the development of the Hector cell (maximum of $15 \mathrm{~km}$ at 12:50, Fig. 6a, b). This is why N23 can be classified as type A (Table 1).

N29 (a detailed description of this event can be found in Gentile et al., 2014) is also type B; the development of this convective event is characterized by non-precipitating and well-organized cells during the first stage that ends as weak precipitation starts. Hence, the cells merge into a convergence line, that, interacting with the south sea breeze front and strengthened by a channeling effect, produces an intense growth of the convection. This phase corresponds to the mature stage, which is characterized by a cloud top height reaching $18 \mathrm{~km}$ (Fig. 13a, b of Gentile et al., 2014).

The N11 dynamical evolution is characterized by intense convective activity leading to type B development: a first cell appears in the northern part of the islands at 15:50 LST that triggers the vigorous Hector cell. A maximum height of $19-20 \mathrm{~km}$ is reached at 17:10LST in the middle area of the Tiwi Islands (Fig. 6c, d). Similarly for N17 (type B), the gust front, related to a first precipitating cell which developed at 15:50 LST in the eastern part of the Tiwi Islands, interacted with the south sea breeze front, leading to a maximum height of $16-17 \mathrm{~km}$ at $16: 30 \mathrm{LST}$ (Fig. 6e, f). N20 is also classified as type B (Table 1); its first stage is characterized by 

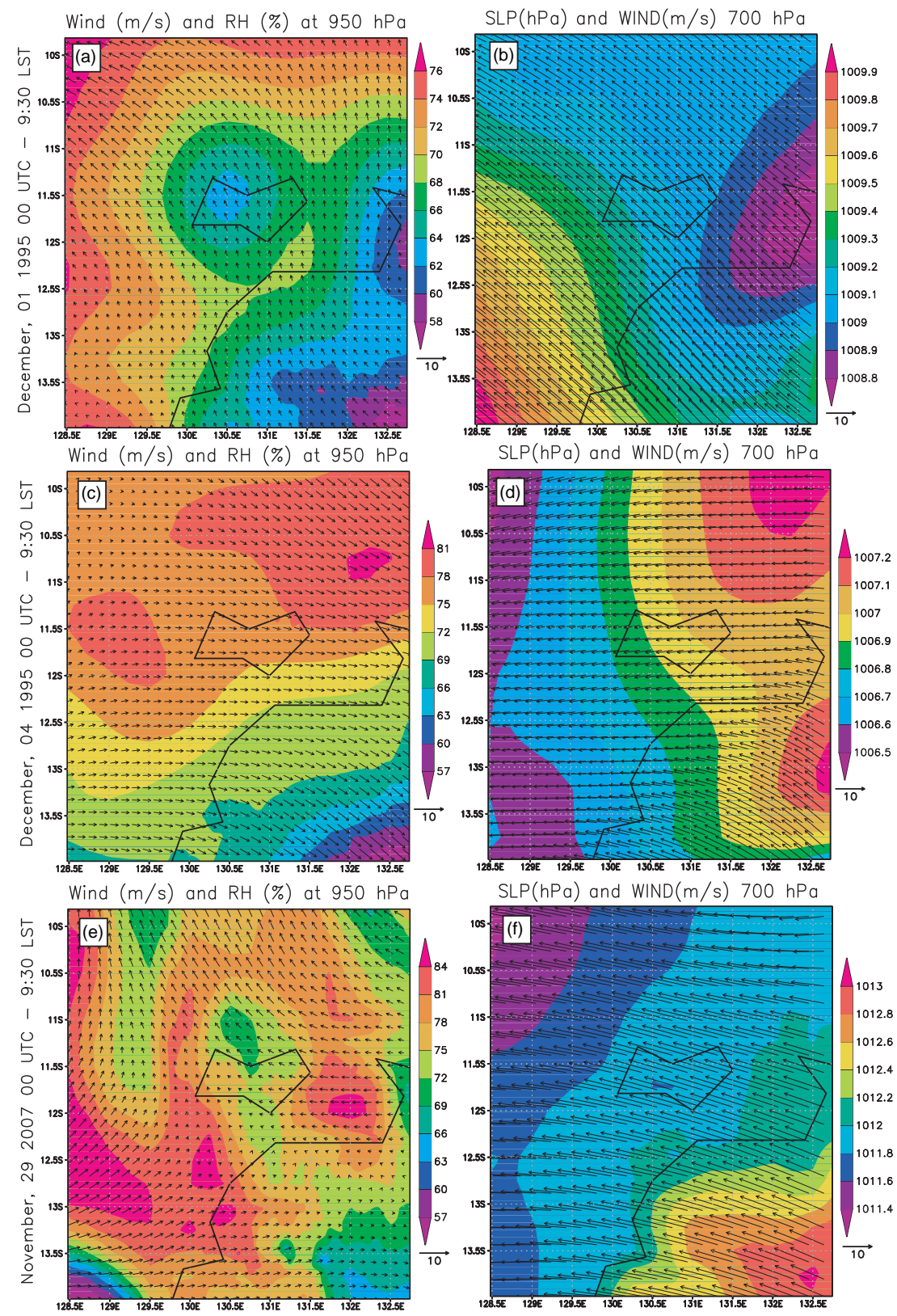

$\operatorname{SLP}(\mathrm{hPa})$ and $\operatorname{WIND}(\mathrm{m} / \mathrm{s}) 700 \mathrm{hPa}$

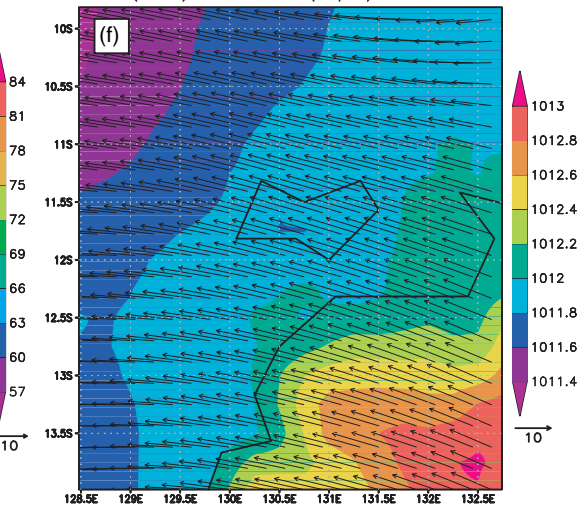

Figure 1. ECMWF analysis over the Tiwi Islands at 00:00 UTC for D1, D4 and N29. Panels (a, c, e) report surface wind and relative humidity at $950 \mathrm{hPa}$; panels $(\mathbf{b}, \mathbf{d}, \mathbf{f})$ report sea level pressure in filled contours and wind flow vectors at $700 \mathrm{hPa}$.

aligned non-precipitating convective cells. These cells lead to an initial double structure that merges into a unique Hector cell at 17:10 LST. The maximum development shows a height of $17 \mathrm{~km}$ (Fig. 6g, h). Finally, F6 (a detailed description of the meteorological characteristics is given in Ferretti and Gentile, 2009) is characterized by two precipitating cells: the first one developing at 12:30 LST in the eastern part of Tiwi Islands, then decaying at 14:30 LST in the central area, and the second deep cell reaching maximum reflectivity of $45-50 \mathrm{dBz}$ at 15:30 LST with a maximum cloud top of $16 \mathrm{~km}$ (Fig. 14e, f of Ferretti and Gentile, 2009). The interaction be- tween the gust front of the decaying first cell with the south breeze front is the triggering mechanism for this Hector event (type B).

\section{Cloud total condensate and vertical velocity profiles for the events}

In order to better understand the mechanisms leading to different convective structures for these Hector events, the vertical structures of the storms are analyzed in terms of total condensate (Crook, 2001). With this aim, MM5 simulations 

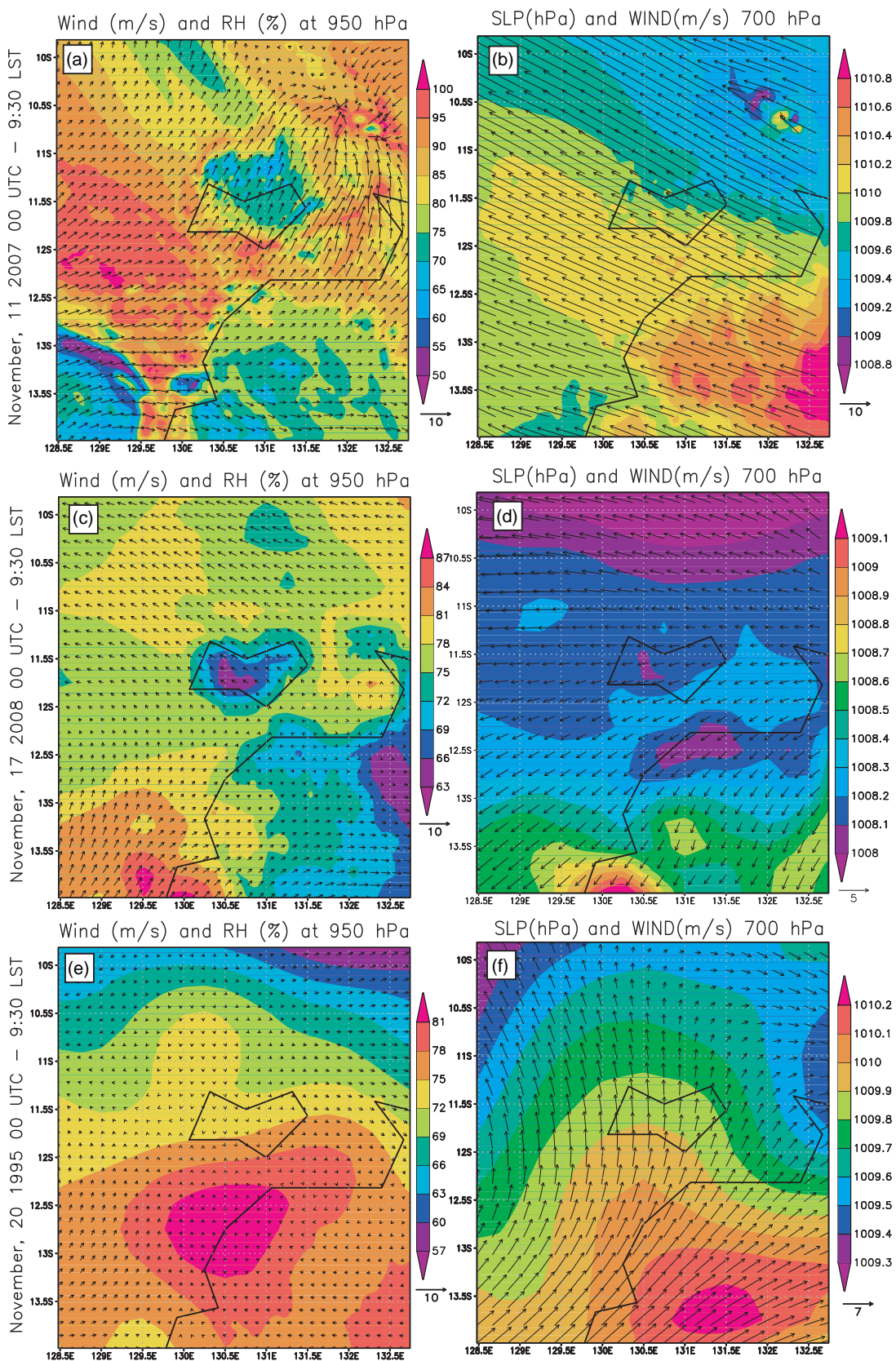

Figure 2. ECMWF analysis over the Tiwi Islands at 00:00 UTC for N11, N17 and N20. Panels (a, c, e) report surface wind and relative humidity at $950 \mathrm{hPa}$; panels $(\mathbf{b}, \mathbf{d}, \mathbf{f})$ report sea level pressure in filled contours and wind flow vectors at $700 \mathrm{hPa}$.

are used to extract the mean vertical profile of the cloud total condensate (sum of all hydrometeors) and the vertical velocity for each event at the maximum stage (Fig. 7). The maximum stage is selected based on the time of the storm maximum height. The profiles are spatially averaged for each layer within the volume encapsulating Hector at a specific time. The maximum of the mean vertical velocity profile is approximately $0.9 \mathrm{~m} \mathrm{~s}^{-1}$ for N11 (Fig. 7d), and the largest vertical velocity is $35 \mathrm{~m} \mathrm{~s}^{-1}$ for the same event. D1, D4, N29, N17 and the first and the second cell, for N27 and
$\mathrm{N} 30$, respectively, have a maximum updraft value that exceeds $20 \mathrm{~m} \mathrm{~s}^{-1}$. If it is spatially averaged, it does not exceed $0.6 \mathrm{~m} \mathrm{~s}^{-1}$. The values of the maximum vertical velocity for N30 are very close to those obtained with the LES simulations by Dauhut et al. (2014). The maximum updraft obtained by MM5 is approximately $22 \mathrm{~m} \mathrm{~s}^{-1}$, sustained for a height up to $8-16 \mathrm{~km}$ (not shown) and the structure is very close to the one simulated by Meso-NH, using horizontal resolutions of 400, 200 and $100 \mathrm{~m}$ (Fig. 3a in Dauhut et al., 2014). 

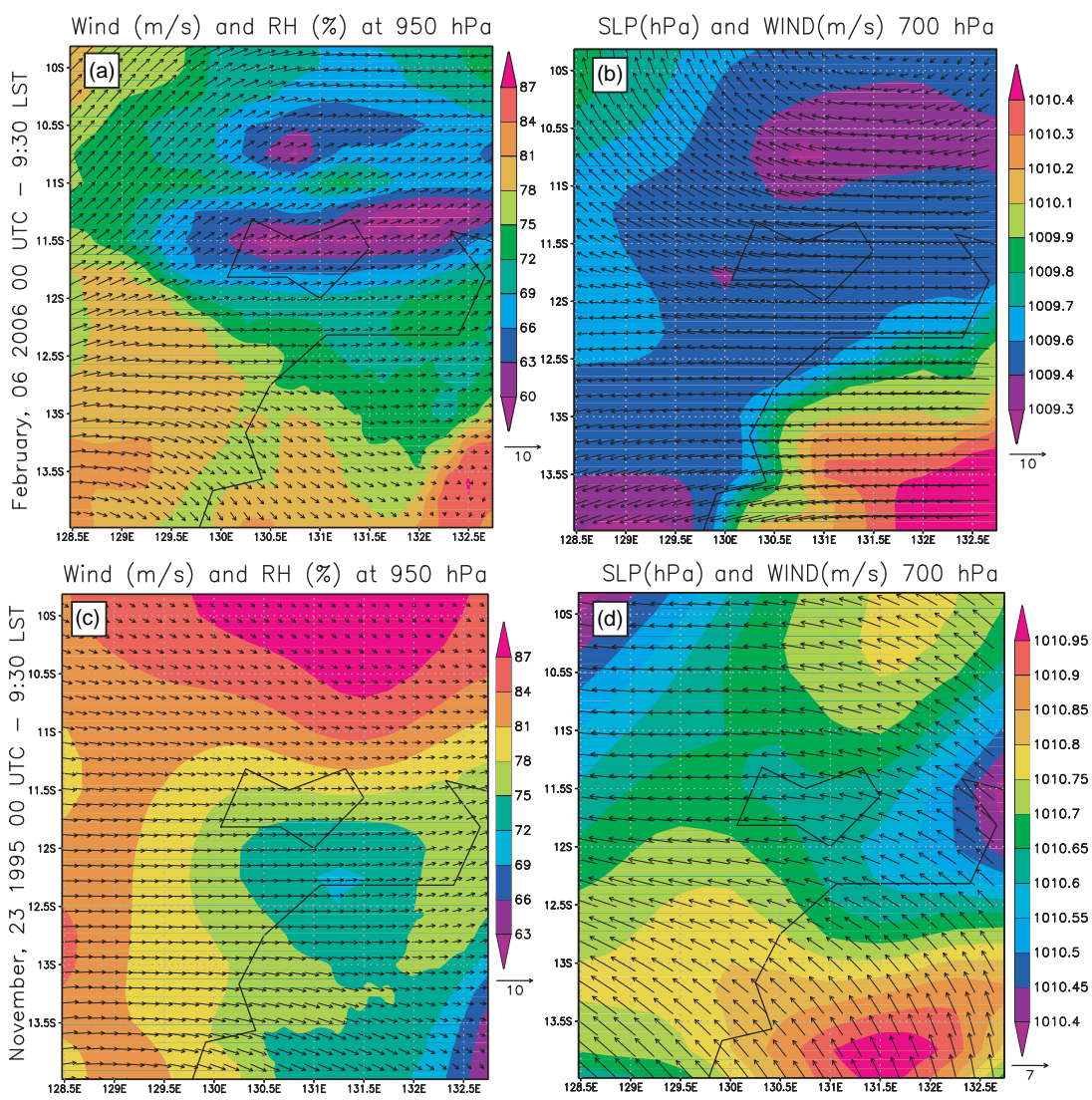

Figure 3. ECMWF analysis over the Tiwi Islands at 00:00 UTC for F6 and N23. Panels (a, c) report surface wind and relative humidity at $950 \mathrm{hPa}$; panels $(\mathbf{b}, \mathbf{d})$ report sea level pressure in filled contours and wind flow vectors at $700 \mathrm{hPa}$.

The absolute maximum of the total condensate matter is approximately $1.5 \mathrm{~g} \mathrm{~m}^{-3}$ for the first cell of N27 (Fig. 7e), but the largest vertical velocity is not reached by this event.

The vertical velocity profiles (Fig. 7b, d, f) present common features for most of the events. At the lower level, a weak downdraft related to the precipitating hydrometeors prevails, and at the upper level, a very strong updraft can be detected, associated with the latent heat release due to the condensation process. In addition, a downdraft peak in the vertical velocity profile is found at the same level of a relative maximum in the total condensate profile for $\mathrm{N} 11$ at $2 \mathrm{~km}$ (Fig. 7c, d), the second cell of N30 at $3 \mathrm{~km}$ (Fig. 7e, f) and the first cell of N27 at 3-4 km (Fig. 7e, f). These features would suggest that the downdraft is related to the sinking due to melting or evaporation cooling, and the total condensate maximum corresponding to the production of rain or melted graupel. Moreover, the total condensate maxima are at higher altitude than the updraft peaks as for N29, N20 and N11 (Fig. 7b, d); these events have a maximum updraft at approximately $12 \mathrm{~km}$ and show a relatively large amount of total condensate up to $14-16 \mathrm{~km}$ (Fig. 7a, c). However, if the maximum vertical velocity is positioned at lower levels, the most part of the hydrometeors' distribution is at lower levels too. A clear example is the first cell of the N27 (Fig. 7e, f): the maximum updraft is located at approximately $4 \mathrm{~km}$ and the largest part of the hydrometeors is below $10-12 \mathrm{~km}$.

The maximum total condensate and its vertical distribution may be related to the strength of convection, which is generally stronger if generated by the convergence of downdraft of previous cells and the sea breeze front (type B) than the one generated by the convergence of the two sea breeze fronts (type A) (Crook, 2001). Therefore, larger vertical velocities are expected for type B events; indeed, the largest vertical velocity is found for N11, which is type B. The previous analysis suggests that the strength of convection largely contributes to the vertical distribution of the total condensate. Therefore, the structure of these Hector events agrees with the hypothesis of Crook (2001) and allows it to be established that the strength of the event is proportional to the total condensate. However, the large variability of the total condensate vertical distribution among type $\mathrm{A}$ and $\mathrm{B}$ events suggests that other parameters play an important role beside the strength of convection. 

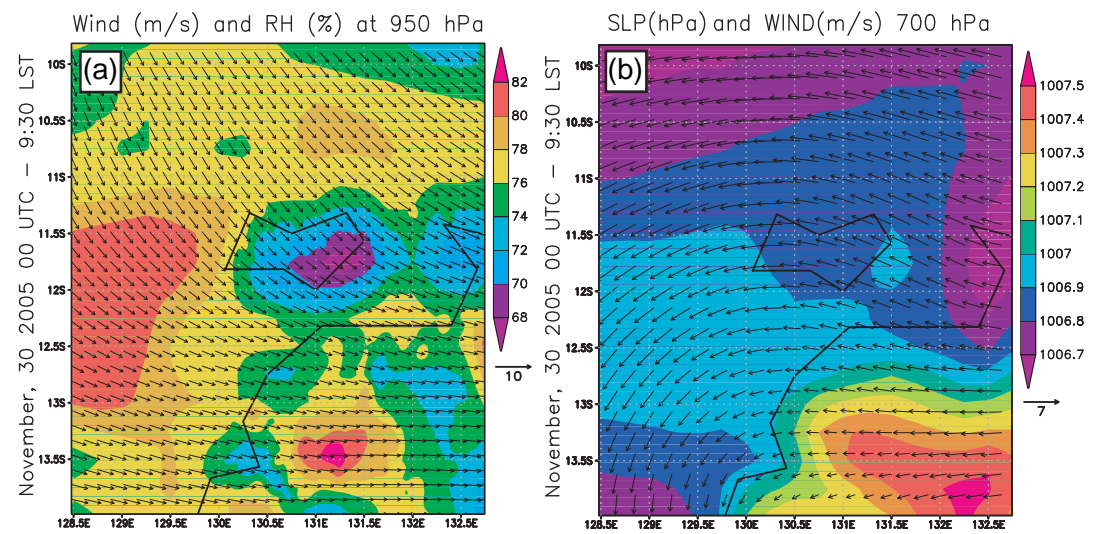

Wind $(\mathrm{m} / \mathrm{s})$ and $\mathrm{RH}(\%)$ at $950 \mathrm{hPa}$
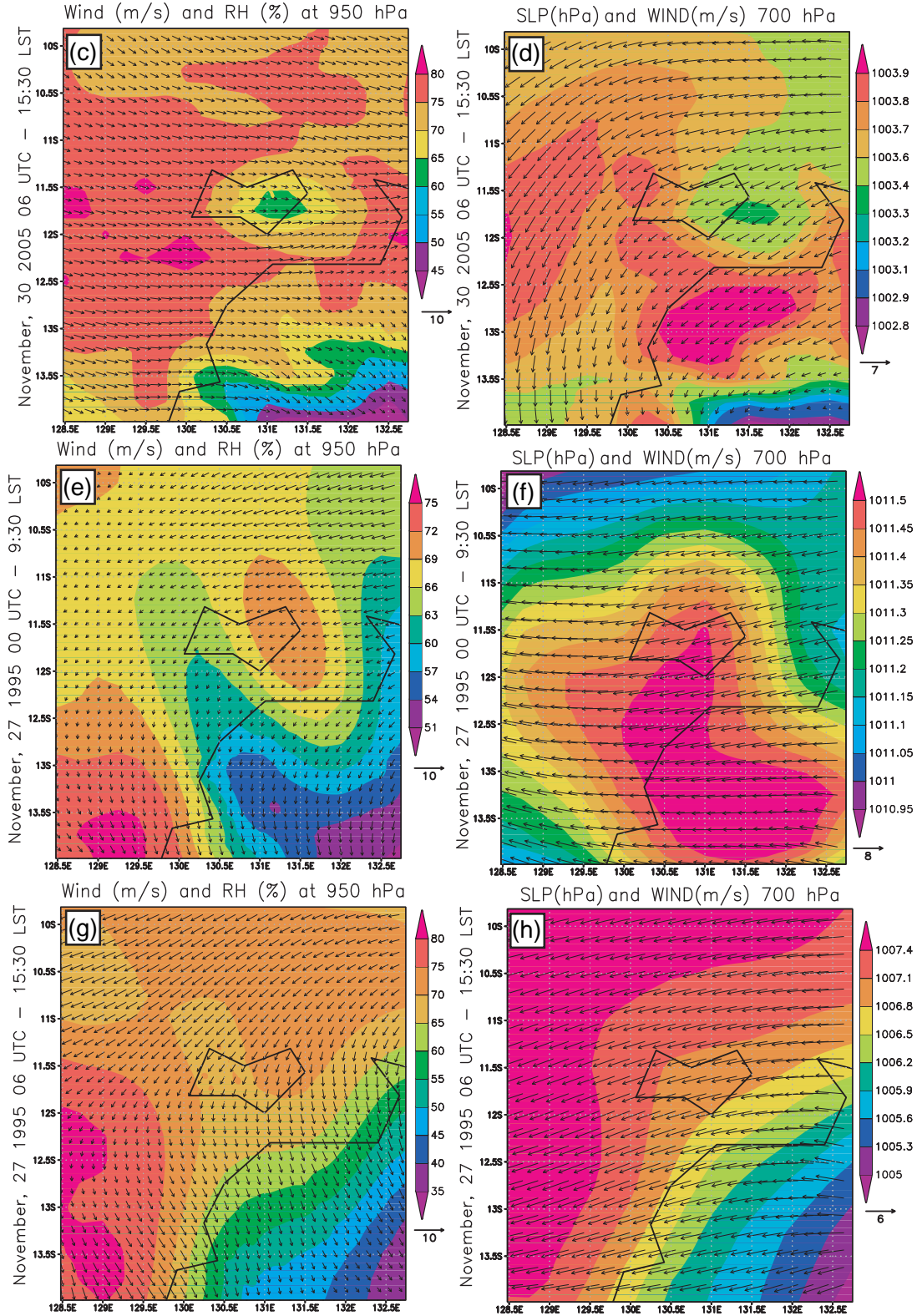

Figure 4. ECMWF analysis over the Tiwi Islands for N30 and N27 at 00:00 UTC for the first cell and at 06:00 UTC for the second one. Panels (a, c, e, g) report surface wind and relative humidity at $950 \mathrm{hPa}$; panels $(\mathbf{b}, \mathbf{d}, \mathbf{f}, \mathbf{h})$ report sea level pressure in filled contours and wind flow vectors at $700 \mathrm{hPa}$. 

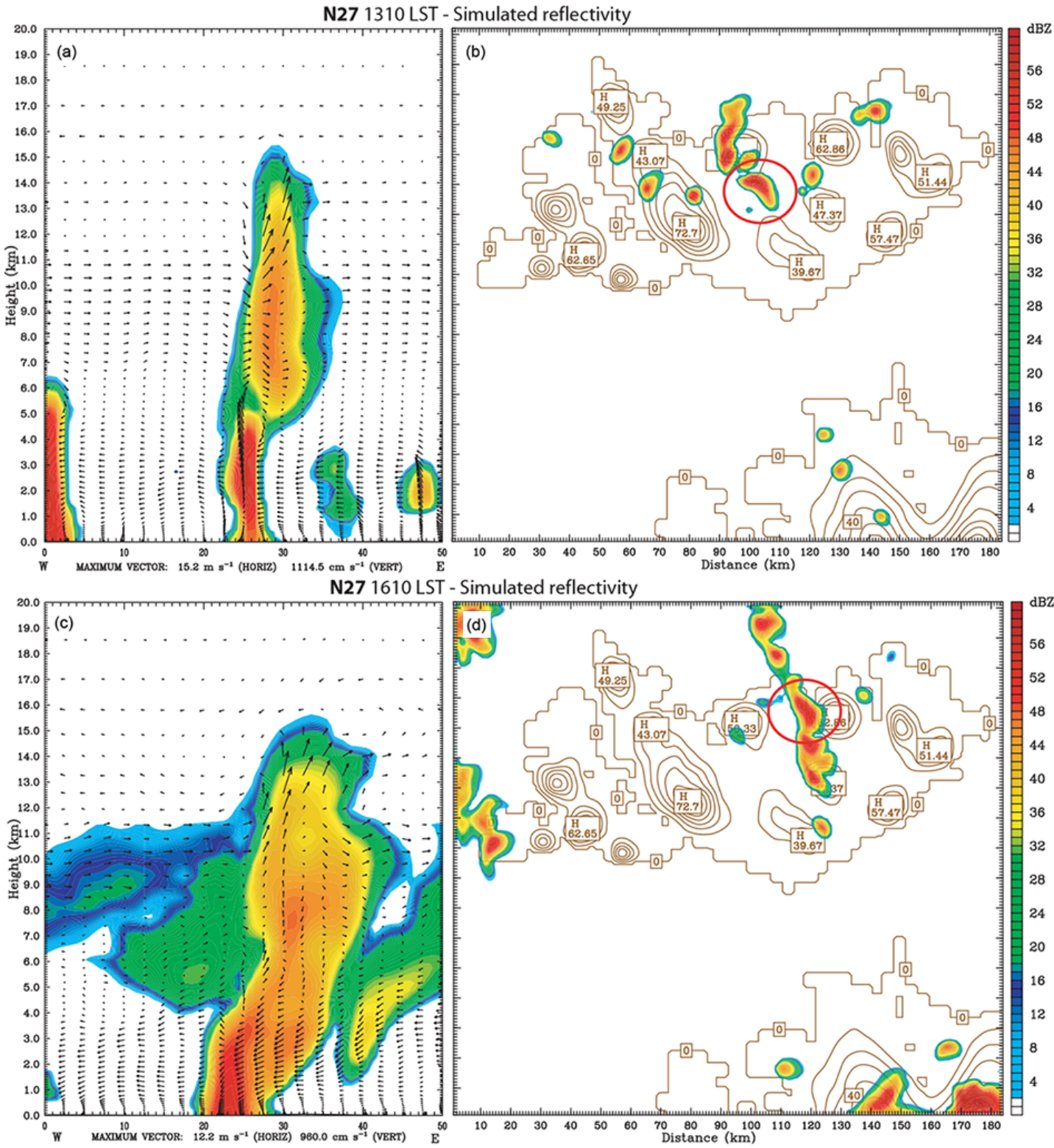

Figure 5.

\section{Crook's test to detect triggering factors}

In this section the analysis of the real events is carried out, using Crook's diagrams as a benchmark.

Based on ideal studies of Hector, Crook (2001) suggested that the amount of total condensate is strongly related to the low-level moisture, in terms of CAPE, as well as to the surface wind velocity and direction. Therefore, a model-aided analysis of the total condensate and of a few meteorological parameters (wind speed and direction, and CAPE), as used by Crook (2001), may help to highlight the most important factors for previous Hector events. With this aim, the same analysis performed by Crook (2001) is applied to the real
Hector events analyzed in this study, but some differences are obviously present. The possibility of changing the meteorological parameters, for example, keeping one field constant as is done by Crook (2001), is not applied because its disruptive effect on Hector has already been verified. Indeed, for real events, the variation of a parameter causes a lack in the development of Hector. For example, in the work of Ferretti and Gentile (2009), the halving and the increasing of the initial water vapor content disabled the development of Hector.

The following MM5 meteorological parameters are used for the analysis: low-level moisture, in terms of CAPE, surface wind speed and direction. Following Crook (2001), the variables are analyzed at the model start time, which is sev- 

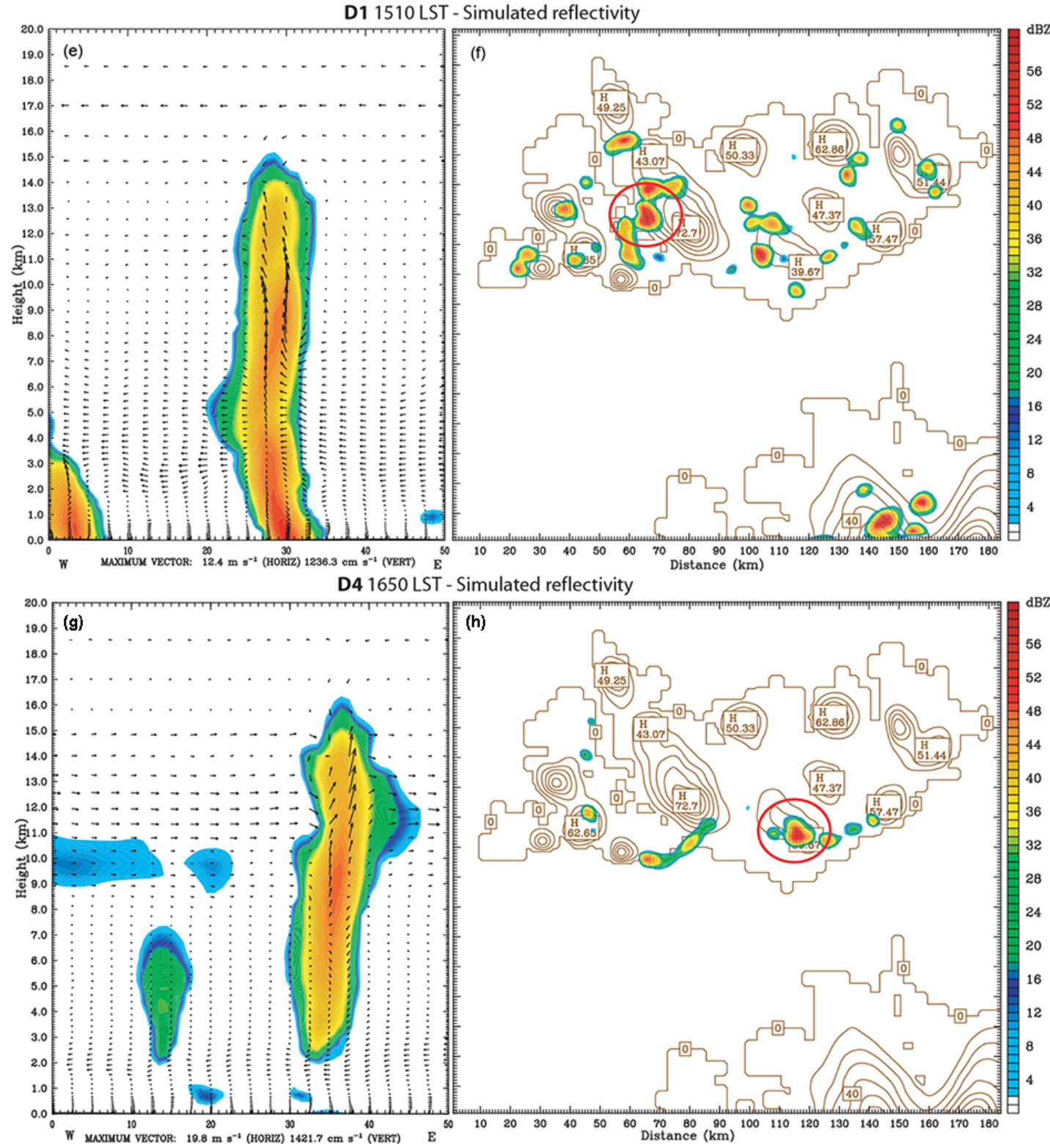

Figure 5. Sections at the maximum development of the Hector events N27 (double-cell), D1 and D4. (a, c, e) Simulated vertical radar reflectivity (dBZ; filled color) and vertical wind; the section is taken longitudinally along the red circle reported in the right panel. (b, d, f) Horizontal radar reflectivity (dBZ; filled color) and topography (brown).

eral hours before the development of Hector. For the single events and for the first cell of double events, the analysis is performed at 08:30 LST, whereas for the second cell of double events, the ending time of the first cell is taken as a reference: 15:10 LST for N30 and 15:30 LST for N27.

All the meteorological parameters are analyzed versus total condensate and mean lifting (vertical velocity at $500 \mathrm{~m}$ ) as in Crook (2001). The vertical velocity is extracted $3 \mathrm{~h}$ before the maximum development of Hector and is averaged all over the island surface. The total condensate, conversely, is averaged within the volume encapsulating Hector at the maximum stage. CAPE, surface wind speed and direction are also averaged all over the surface of the Tiwi Islands. With the aim of understanding the convective response to the flow direction either along the major $\left(90^{\circ}\right)$ or minor axes $\left(0^{\circ}\right)$ of the islands, the wind direction is projected in the first quarter of the wind rose.

Crook (2001) analyzed the vertical velocity wind with respect to the surface wind velocity and direction (Fig. 7b, c in Crook, 2001), related to shear and no-shear conditions. Hence, Fig. 8 shows the results by Crook and the Hector events, indicated by gray lines, and 12 symbols, represent- 

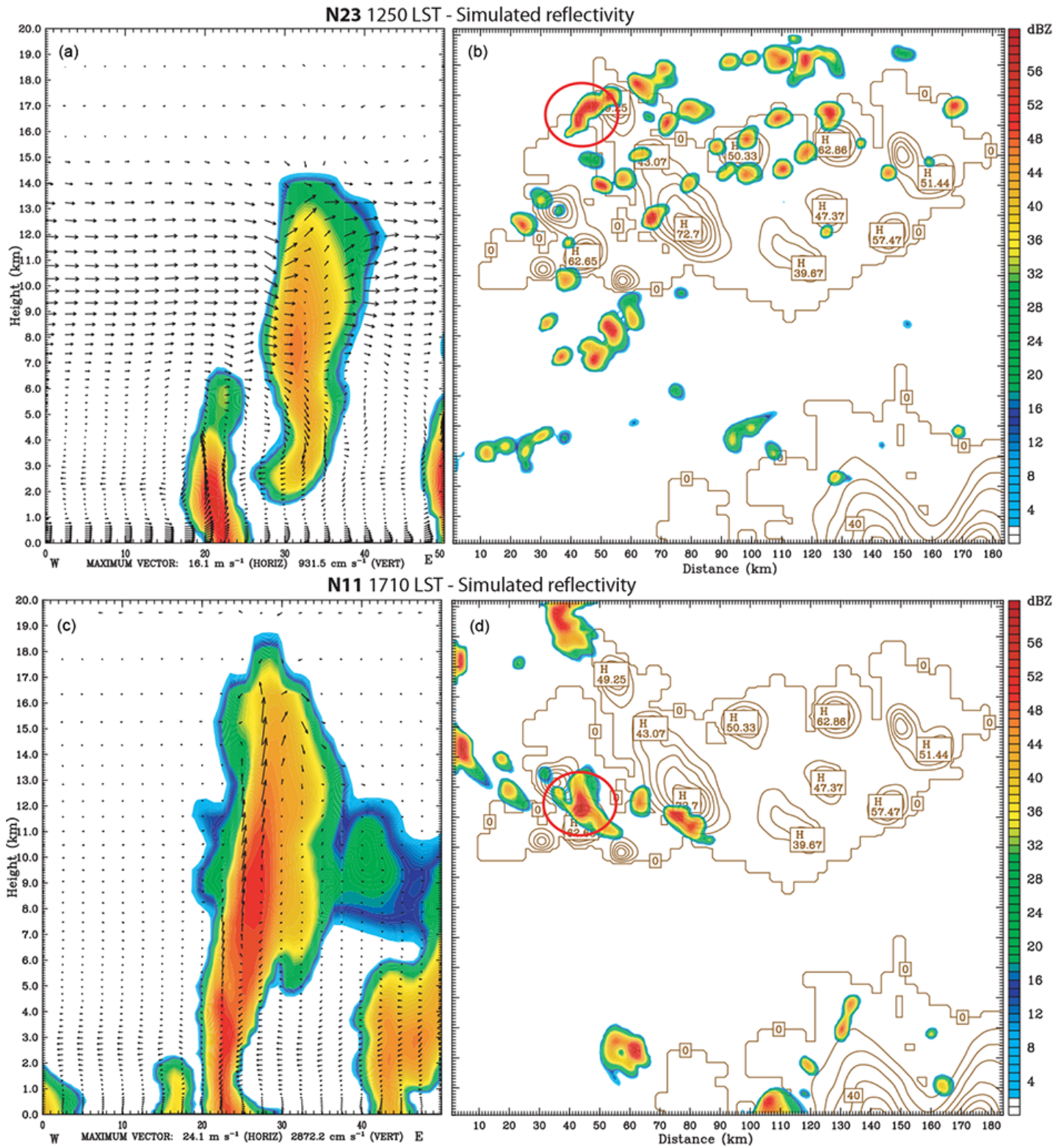

Figure 6.

ing the Hector events. A few events closely follow the shear (F6, N20 and the second cell of N27 and N30) and no-shear (D1, N29) lines (Fig. 8a) or they belong to the right zone (i.e., no shear zone for the first cell of N27), confirming for the shear events the correlation between the decrease of the vertical velocity and the surface wind increase. A few cases do no show any specific signal, probably because the real atmosphere is more complex than the ideal one, and more than one parameter contributes to the vertical lifting, as for example the topography or the convergence line. Therefore, the ideal response can be used to sort the events: the closer the position of the event in the diagram is to the "ideal" one, the more the meteorological parameter contributes to the convective strength.

The second cells of both the double structure events show a stronger surface wind speed than the corresponding first cell; this is due to the gust front associated with the downdraft of the previous convective cell. This is why the double-cell events are not aligned with the others.

A similar analysis is performed for the vertical velocity as a function of the surface wind direction. The results clearly show (Fig. 8b) that most of the events are located in the right position except for four events: D1, N17, N29 and N23, suggesting difficulties in the real atmosphere to completely separate the two regimes. However, it roughly confirms the 

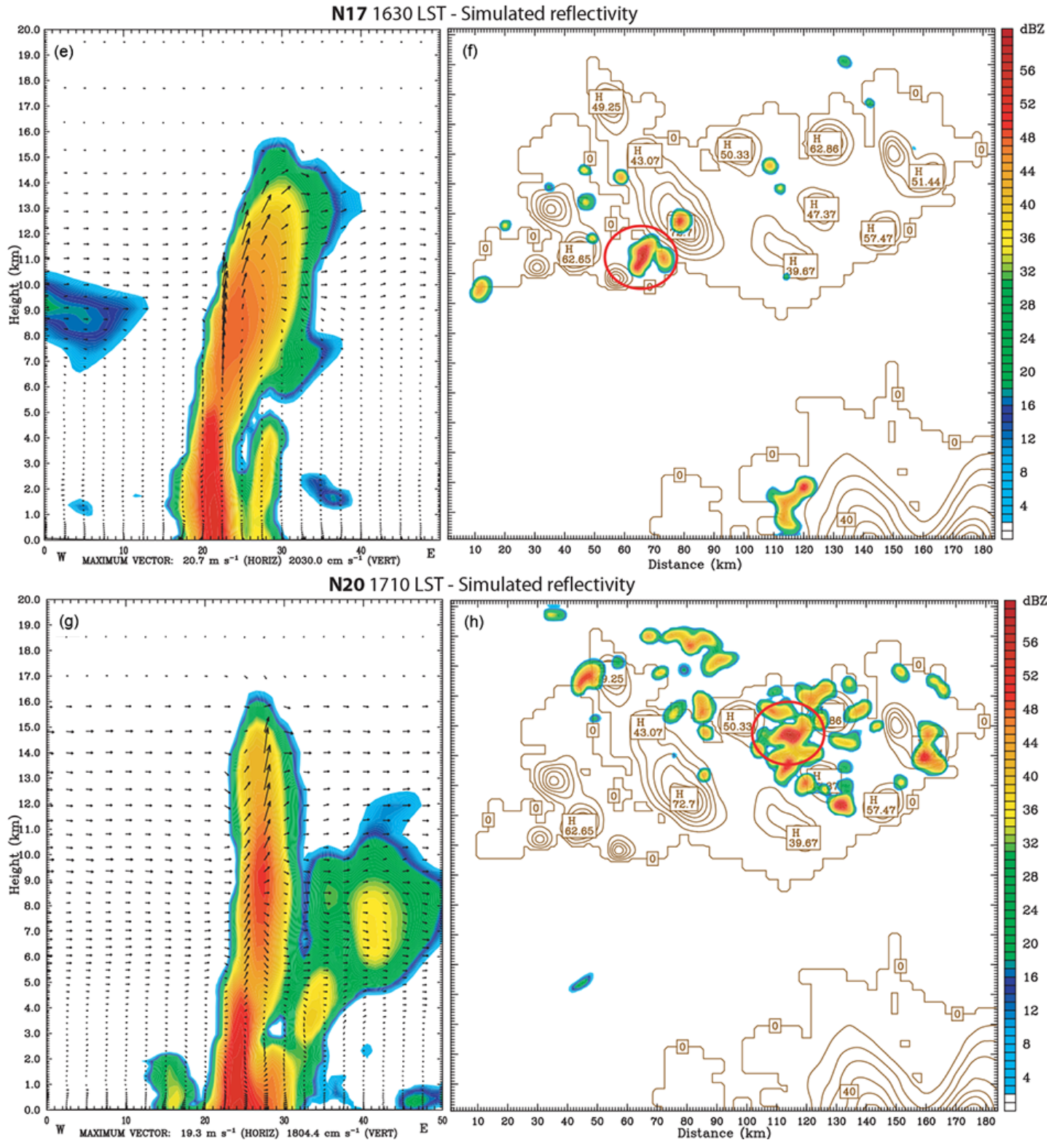

Figure 6. Sections at the maximum development of the Hector events N23, N11, N17 and N20. (a, c, e) Simulated vertical radar reflectivity (dBZ; filled color) and vertical wind, the section is taken longitudinally along the red circle reported in the right panel. (b, d, f) Horizontal radar reflectivity (dBZ; filled color) and topography (brown).

increase of the vertical velocity when the flow is eastward $\left(90^{\circ}\right)$. This supports the hypothesis of greatest lifting when the flow is along the major axis of the island as assessed by Carbone et al. (2000) and Crook (2001). It is useful to highlight that the wind direction related to the second cells of the double events does not show a clear signal, because at this time, the sea breeze regime is either well developed or destroyed, and "leftovers" from the first cell affect the environment. Therefore, their positions in the graph have an uncertainty larger than the one for the single-cell events.
The analysis of the total condensate versus wind speed (Fig. 9a) shows that most of the Hector events are aligned along a line with a slope close to that of Crook's study, but an intercept that is smaller (gray dotted line in Fig. 9a), suggesting a sort of bias between Crook's ideal and the real atmosphere. This disagreement can be explained by speculating that the real events need weaker surface wind than the ideal ones to produce the same total condensate. Based on this hypothesis, a new reference line can be assumed, then only two events appear outside of the distribution, the second events of the double Hector N27 and N30 (Fig. 9a, white square 

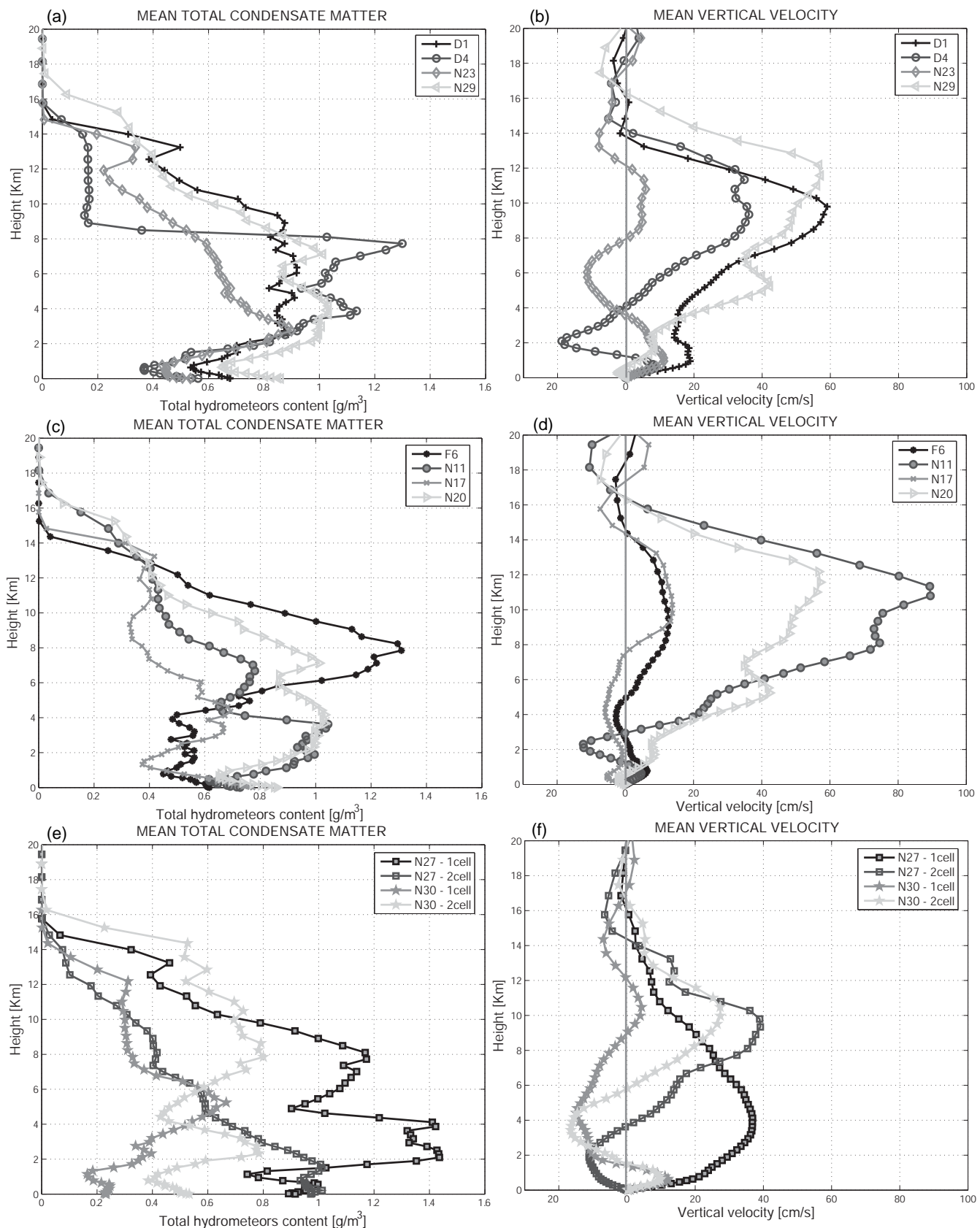

Figure 7. MM5 mean vertical profiles of cloud total condensate (sum of all hydrometeors) and vertical velocity at the maximum stage. Profiles are averaged for each layer within the volume encapsulating Hector.

and white star, respectively). Both events have larger wind speed than the expected one on equal terms of normalized total condensate. The absolute maximum of total condensate is reached by the first cell of $\mathrm{N} 27$, whereas the second cell shows approximately a $65 \%$ of the first cell total condensate. On the contrary, for N30 the second cell is stronger than the first one, in terms of cloud total condensate. This is partly due to the leftovers of the previous cell because of the very short time interval $(1 \mathrm{~h}$ and $20 \mathrm{~min})$ that occurred between the two maxima; whereas for $\mathrm{N} 27$, the second cell develops $3 \mathrm{~h}$ later than the first one, making the two cells more independent than the previous event. Hence, the hypothesis of the increase of the total condensate as the surface wind speed decreases (Fig. 9a) is still confirmed, but below $4 \mathrm{~m} \mathrm{~s}^{-1}$ for all single-cell events and the first cell of double ones. Based on the results of the dry linear and non-linear models, Crook (2001) assessed that the relationship between convective strength and low-level convergence (i.e., surface 

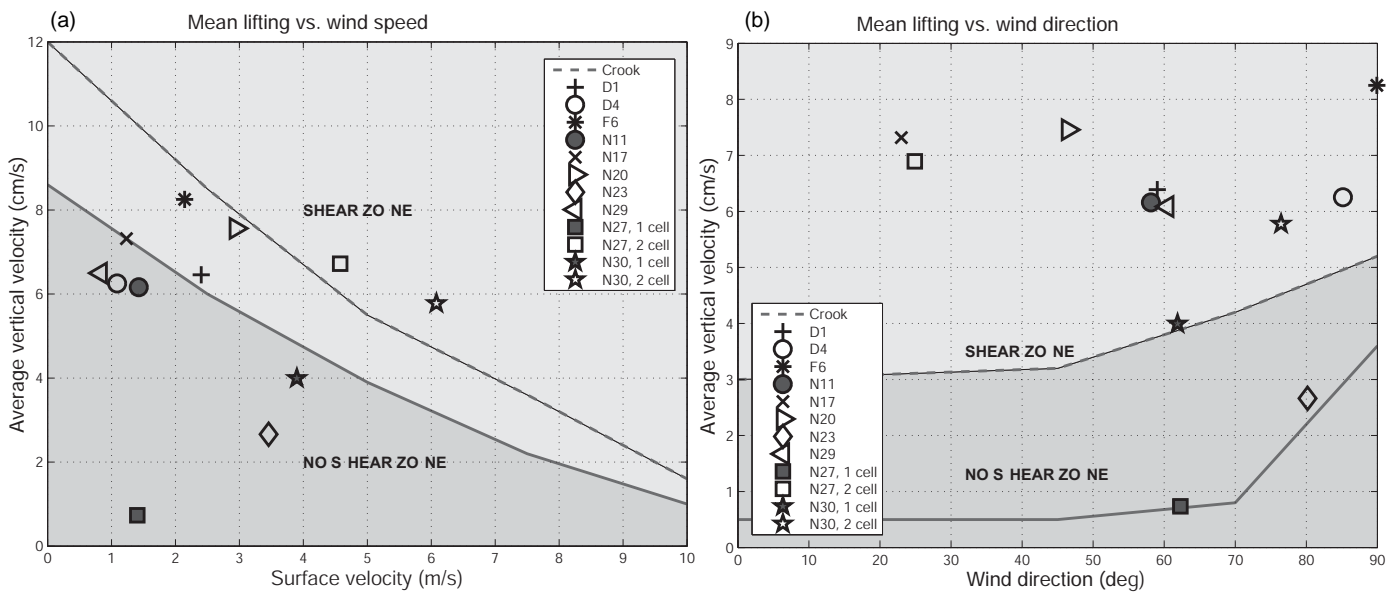

Figure 8. Crook's test: panels (a) and (b) show vertical velocity at $500 \mathrm{~m}$ extracted $3 \mathrm{~h}$ before the maximum development versus surface wind speed (a) and surface wind direction (b), both extracted at the start time. The figure reports two different regimes with a sheared (light gray, dashed line) and unsheared flow (dark gray, solid line) as studied by Crook.

wind speed) is not strictly monotonic because the convective strength did not continue to increase as the flow decreases below $4 \mathrm{~m} \mathrm{~s}^{-1}$. The 12 Hector events also reproduce a monotonic relationship also below $4 \mathrm{~m} \mathrm{~s}^{-1}$ (Fig. 9a). This discrepancy between the simulations of the real events and the Crook experiments is not surprising and it may be due to the differences between the model's assumptions and the use of an idealized sounding in the Crook study.

All Hector events, except the second cell of N27 and N17, confirm the increase of the total condensate if the low-level flow is along the major axes as shown by the plot of the total condensate versus the wind direction (Fig. 9b), but a spread along the Crook "theoretical" line is found for the real events. As for the mean lifting versus wind direction (Fig. 8b), the major difference between Crook ideal behavior and real behavior is found for the surface wind, of which direction is close to the minor axes. However, Crook's hypothesis of maximizing the low-level convergence if the flow is aligned along the major axis of the Tiwi Islands is confirmed.

Finally, similarly to what was done by Crook (2001), the total condensate versus the low-level moisture, expressed in terms of CAPE, is analyzed. The Hector events do not show a clear signal, but they show a slight increase of the total condensate as the CAPE increase is found, except for the first cell of N27. This is completely outside of Crook's line (Fig. 9c, gray square). Moreover, on the contrary to what was found by Crook (Fig. 13a in Crook, 2001), no maximum is found for the total condensate versus CAPE because of the lack of Hector's values around the theoretical maximum; hence it is not possible to assess its occurrence.

\subsection{Main features of the Hector events}

Based on the previous analysis and on the brief summary of the main characteristics of these Hector events given in Table 1, some important highlights can be inferred using the surface wind speed, surface wind direction and CAPE. Each event seems to be driven by particular meteorological conditions, whose contributions to the convective strength have been estimated and summarized in Table 2 . This computation is performed by evaluating the distance between the real point and its corresponding ideal one. The lines reported in Figs. 8 and 9 show the ideal conditions for the development of Hector. As the real points get closer to the ideal lines, the more the meteorological conditions are suitable for the development of Hector. Once the percentages from surface wind speed, surface wind direction and CAPE are obtained, the total contribution from the three parameters is normalized to 100 . Therefore, the percentage of influence for each parameter is calculated and the following conclusions can be drawn.

1. D1 and $\mathrm{N} 29$ events, both type B, produce a large amount of total condensate (respectively 75 and $82 \%$ of the maximum), suggesting a strong convective strength. A similar contribution $(\approx 33 \%)$ to the development of Hector is found for the three meteorological parameters, with a prevalence of favorable surface flow direction for the first event and slow surface wind velocity for the second one (Table 2).

2. D4, F6, N17, N23 and the first cell of N27 have a total condensate ranging between 55 and $65 \%$ of the maximum (except for the first cell of N27 that is the maximum). The convective development is due mainly (percentage of its influence from 47 to $62 \%$ ) to just one meteorological parameter: surface flow direction for D4, F6 and N24, and slow wind speed for N17 and N27. 


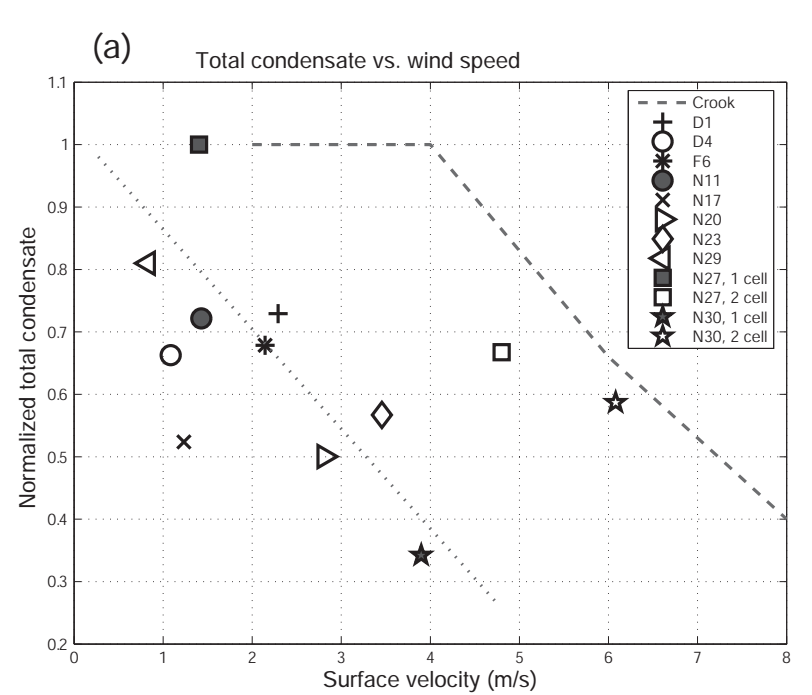

(b) Total condensate vs. wind direction

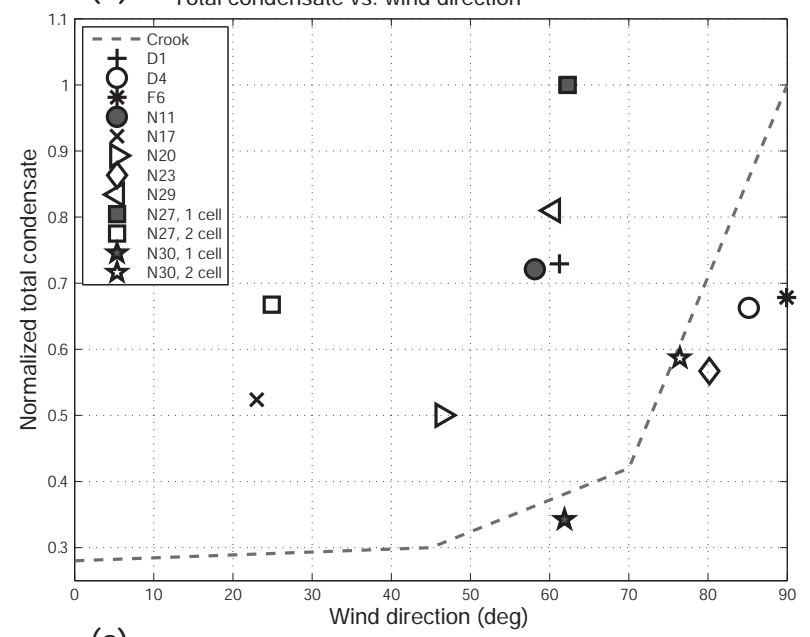

(c)

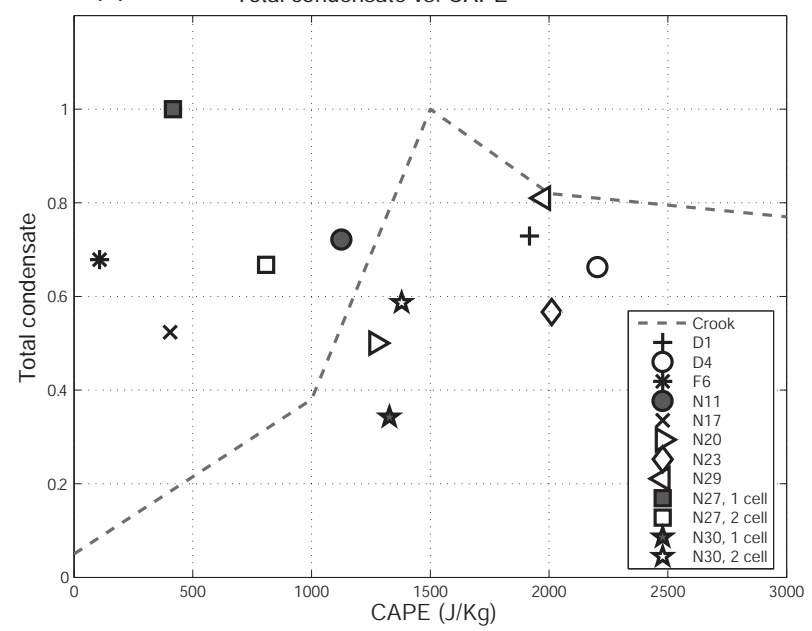

Figure 9. Crook's test: normalized total condensate extracted at the maximum stage and averaged into the Hector volume versus surface wind speed (a), surface wind direction (b) and CAPE (c), extracted at the start time. The dashed gray line reports the Crook ideal trend, and the light gray dotted line in panel (b) reports the derived real trend.
Table 2. Percentage of influence for the meteorological parameters on the convective development of the Hector events.

\begin{tabular}{lccc}
\hline Events & $\begin{array}{c}\text { Surface wind } \\
\text { speed }\end{array}$ & $\begin{array}{c}\text { Surface wind } \\
\text { direction }\end{array}$ & CAPE \\
\cline { 2 - 4 } & \multicolumn{3}{c}{$(\%)$} \\
\hline D1 & 33 & 35 & 32 \\
D4 & 26 & 47.5 & 26.5 \\
F6 & 39 & 57 & 4 \\
N11 & 27 & 34 & 39 \\
N17 & 62 & 18 & 20 \\
N20 & 32 & 25.5 & 42.5 \\
N23 & 13 & 50 & 37 \\
N27-1 & 47 & 38.5 & 14.5 \\
N27-2 & 42 & 20 & 38 \\
N29 & 37 & 31 & 32 \\
N30-1 & 17.5 & 36.5 & 46 \\
N30-2 & 22 & 38 & 40 \\
\hline
\end{tabular}

Another important contribution for three of these events is also found: the surface wind speed for F6, the lowlevel moisture for $\mathrm{N} 23$ and the wind direction for the first cell of N27.

3. The development of N11 and both cells of N30 is sustained by the "right" CAPE value (Crook, 2001) and by the wind direction. Indeed, the flow blows along the major axis of the Tiwi Islands, maximizing the lowlevel convergence. The N30 (type B) produces a larger amount of total condensate ( $58 \%$ for the second cell vs $35 \%$ of the first one) than type A, suggesting a stronger convective strength; the most important parameter to justify it is the low-level wind shear. Indeed, Crook's analysis allows the change in the regime from no-weak shear for the first cell to strong shear for this second cell to be highlighted; whereas the other meteorological parameters are similar for both. The N30 (type A) produces the smallest amount of total condensate, suggesting a weak convective strength; several meteorological parameters justify this. The large surface velocity, the wind direction and a weak shear do not sustain Hector, whereas CAPE is the only parameter which acts positively.

4. N20 and the second cell of N27 are characterized by a total condensate around 50-60\% of the maximum content but the events present a strong mean lifting. The convective strength for both events mostly depends on two parameters with different weights. The main contribution (approximately $42 \%$, see Table 2 ) comes from the slow wind speed for N27 and CAPE for N20. Moreover, slow wind speed and CAPE contribute $35 \%$ to N20 and N27 development, respectively. 
In summary, the previous analysis highlights the role of the meteorological parameters in defining the Hector convective strength, but it does not allow a specific parameter to be highlighted, as Crook assessed for the low-level moisture, to establish the Hector typology. Moreover, the relationship between both the total condensate and mean lifting and several meteorological parameters for the Hector events confirms what was found by Crook (2001) within this sensitivity analysis.

\section{Conclusions}

In this study, 12 Hector events are analyzed using MM5 model simulations, with the aim of highlighting the main meteorological parameters and their role in triggering convection. A brief meteorological analysis of the events is performed using CAPE, water vapor, wind speed and direction and typology of convection. Moreover, a comparison in terms of mean total condensate vertical profiles and mean vertical velocity at the maximum development is carried out. The applicability of Crook's hypothesis to real cases is explored, verifying the linear relationship between both the convective strength and the total condensate versus the low-level moisture, expressed in terms of CAPE, surface wind speed and direction. Crook's tests allow the following to be concluded.

1. The strength of convection, in terms of mean lifting and total condensate, increases if the wind direction tends to be parallel to the major axes of the Tiwi Islands and if the wind speed surface decreases.

2. Crook's assumption on the low-level moisture as the parameter that differentiates between type A and B modes of convection is not confirmed.

3. The previous hypothesis is verified for the two N30 Hector cells, where the second cell (type B) has a larger low-level moisture and convective strength than the first cell (type A). This would suggest the applicability of a type A or B classification based on the low-level moisture for events developing in the same meteorological conditions only. That means it cannot be generalized to all real cases.

4. The meteorological parameters contributing to the Hector development are only one with an influence coefficient up to $47 \%$ for five events, and two with influence coefficients from $32 \%$ to $46 \%$ for five events. All the parameters contribute by a percentage of $31-37 \%$ for only two cases.

Thanks to their simple orography and shape, the Tiwi Islands can be used as a laboratory to study the triggering factors contributing to convection. Hence, in this context, this study will allow for a better understanding of different meteorological parameters occurring at the onset of convection, even in complex orography regions.
Acknowledgements. NCAR is acknowledged for the MM5 model. ECMWF is acknowledged for data analysis.

Edited by: L. Ferraris

Reviewed by: two anonymous referees

\section{References}

Carbone, R., Wilson, J., Keenan, T., and Hacker, J.: Tropical island convection in the absence of significant topography. Part I: Life cycle of diurnally forced convection, Mon. Weather Rev., 128, 3459-3480, 2000.

Chemel, C., Russo, M., Pyle, J., Sokhi, R., and Schiller, C.: Quantifying the Imprint of a Severe Hector Thunderstorm during ACTIVE/SCOUT-O3 onto the Water Content in the Upper Troposphere/lower Stratospere, Mon. Weather Rev., 137, 24932514, doi:10.1175/2008MWR2666.1, 2009.

Crook, N.: Understanding Hector: the dynamics of Island thunderstorm, Mon. Weather Rev., 129, 1550-1563, 2001.

Dauhut, T., Chaboureau, J., Escobar, J., and Mascart, P.: Large-eddy simulations of Hector the convector making the stratosphere wetter., Atmos. Sci. Lett., 16, 135-140, doi:10.1002/as12.534, 2014.

Dudhia, J., Dave, G., Manning, K., Wang, W., and Bruyere, C.: MM5 Modeling System Version 3, PSU/NCAR Mesoscale Modelling System Tutorial Class Notes and User's Guide, Mesoscale and Microscale Meteorology Division of National Center for Atmospheric Research, Boulder, CO, USA, 2004.

Faccani, C., Ferretti, R., and Visconti, G.: High-resolution weather forecasting over complex orography: sensitivity to the assimilation of conventional data, Mon. Weather Rev., 131, 136-154, 2003.

Ferretti, R. and Gentile, S.: A study of the triggering mechanisms for deep convection in the Tropics using a Mesoscale Model: Hector events during SCOUT-O3 and TWP-ICE campaigns, Atmos. Res., 93, 247-269, 2009.

Gentile, S., Ferretti, R., and Marzano, F.: Investigating Hector convective development and microphysical structure by high resolution model simulations, ground-based radar data and TRMM satellite data, J. Atmos. Sci., 71, 1353-1370, 2014.

Golding, B.: A numerical investigation of tropical island thunderstorms, Mon. Weather Rev., 121, 1417-1433, 1993.

Keenan, T. and Carbone, R.: A preliminary morphology of precipitation system in tropical northern Australia, Q. J. Roy. Meteor. Soc., 118, 283-326, 1992.

Ramage, C.: Role of a tropical "Maritime Continent" in the atmospheric circulation, Mon. Weather Rev., 96, 365-370, 1968.

Saito, K., Keenan, T., Holland, G., and Puri, K.: Numerical simulation of the diurnal evolution of tropical island convection over the maritime continent, Mon. Weather Rev., 129, 378-400, 2001.

Zhu, M., Connolly, P., Vaughan, G., Choularton, T., and May, P.: Numerical simulation of tropical island thunderstorms (Hectors) during the ACTIVE campaign, Meteorol. Appl., 20, 357-370, doi:10.1002/met.1295, 2013. 